\title{
Analyzing Public Perception of Investment Products and Their Decision to Invest (Scope of Community in Manado City)
}

\author{
Meiske Wisye Manopo, Adelaida Joroh, Vincentius Pantow \\ Business Administration Department, Manado State Polytechnic, Manado, Indonesia \\ Email: meiske.manopo@gmail.com, jorohadelaida84@gmail.com, angkyvincent902@gmail.com
}

How to cite this paper: Manopo, M. W., Joroh, A., \& Pantow, V. (2021). Analyzing Public Perception of Investment Products and Their Decision to Invest (Scope of Community in Manado City). Open Journal of Social Sciences, 9, 24-32.

https://doi.org/10.4236/jss.2021.911003

Received: October 4, 2021

Accepted: November 6, 2021

Published: November 9, 2021

Copyright (c) 2021 by author(s) and Scientific Research Publishing Inc. This work is licensed under the Creative Commons Attribution International License (CC BY 4.0).

http://creativecommons.org/licenses/by/4.0/

\begin{abstract}
The purpose of this research is to determine the public's perception of investment products and to determine the public's decision to invest. This study uses a descriptive qualitative approach. This research is carried out on people in the city of Manado. The population in this study are people in Manado City who earn more than five million rupiahs, while the sample is 50 people. The method of collecting data is interview and observation. The results show that the people of Manado City clearly know what their reasons are for investing. The profit in the future is their purpose of investing, of course, considering inflation and considering the cost of education which is getting more expensive by the day. People already know how to manage finances by setting aside some of their income to invest, as evidenced by all of the respondents who have implemented investment instruments with their respective varied choices. Furthermore, the decisions of the people in Manado City to choose investments found the results of the community choosing various investment instruments such as property, gold, deposits, businesses, plantations, forex, foreign exchange, index, stocks, mutual funds, bonds. However, property and gold are the favorites of most people in Manado City.
\end{abstract}

\section{Keywords}

Public Perception, Investment Product, Investment Decision, Manado City, Stock Investment, Property Investment, Gold Investment, Stock Market

\section{Introduction}

\subsection{Background}

The attitude of consumerism that becomes a habit today makes people lack a 
culture of investing. There are still many people who do not realize the importance of having financial management in their personal lives, because people still think that personal financial investment planning is only done by people who have high incomes, or entrepreneurs or in companies, have a high income but do not have an investment plan for their personal finances (Pritazahara, 2015 in Ni Made and Henny, 2017).

https://investasi.kontan.co.id/news Monday, 17 August 2020/18:04 WIB noted that as of the end of July 2020 the number of Indonesian capital market investors registered with PT. The Indonesian Central Securities Depository (KSEI), which consists of stock, mutual funds, and bond investors, has grown by $22 \%$ from 2019, to 3.02 million investors. However, this number is still relatively small when compared to the total population of Indonesia, which per semester 1 of 2020 reached 263.58 million people. Vice president Samuel Securitas Indonesia Muhammad Alfatih assessed that there are still very few Indonesians who are investors in the country's capital market, this is due to the lack of capital market literacy and also the low investment culture in the community.

\subsection{Identification of Problem}

Based on the background, it can be concluded that the identification of the problem is as follows:

- Lack of knowledge about investment.

- There are still very few local investors in the stock market.

- Consumptive behavior of consumers makes it difficult to divide income to invest.

\subsection{Focus and Sub Focus Research}

\subsubsection{Focus}

The first focus in this research is how public's perception about investment product Sub focus.

1) Knowing whether the public knows about investment product and their reasons for investment.

2) Knowing whether the public knows about investment product in the capital market.

\subsubsection{Sub Focus}

The second focus in this research is how people's decisions in investing.

1) Knowing the risks and benefits of investments chosen by the community.

2) Knowing whether the public is aware of the risks of investing in the capital market.

3) Knowing what investment instruments have been carried out by the community.

4) Knowing whether the public has a stock/mutual fund/bond account.

5) Find out why they don't invest in the capital market.

The sub focus above is obtained from the perception variable. According to 
(Walgito, 2010) perception has the following indicators:

1) Absorption of the stimuli

a) Do you know about investment products? If the answer is yes, what are your reasons for investing?

b) Do you know about investment products in the capital market?

2) Understanding

a) Do you know the risk and benefits of this type of investment?

b) Do you know the risk of capital market?

3) Assessment or evaluation

a) What investment instruments have you run in the last few years?

b) Do you have investments in stocks, mutual funds, bonds?

c) If the answer to the previous question is no: What are your reasons for not investing in the capital market?

Sub-focus of investment decision According to Tandelilin (2010) the indicators of investment decision consist of:

1) Expected rate of return

Knowing the risk and benefits of investments chosen by the community.

2) Risk Level

Knowing whether the public is aware of the risks of investing in the capital market.

3) The relationship between return and risk

a) Knowing whether the public has a stock/mutual fund/bond account.

b) Knowing why they do not invest in the capital market.

\subsection{Research Objectives}

1) To find out the public's perception of investment products.

2) To know people's decisions in investing.

\section{Theoretical Basic}

According to (Walgito, 2010) the indicator of perception is:

1) Absorption of stimuli

The stimulus or object is absorbed or received by the five senses, both sight, hearing, touch, smell, and taste alone or together. From the results of absorption or acceptance by the senses, you will get a picture, response, or impression in the brain. The image can be singular or plural, depending on the object of perception being observed. In the brain, images or impressions, both old and newly formed, are collected. Whether or not the picture is clear depends on whether or not the stimulus is clear, the normality of the senses and time, just or a long time ago.

2) Understanding

After the images or impressions occur in the brain, the images are organized, classified (classified), compared and interpreted so that understanding or understanding is formed. The process of understanding or understanding is very 
unique and fast. The understanding that is formed depends also on the old images that the individual has previously (called apperception).

3) Assessment or evaluation

After forming an understanding or understanding, there is an assessment of the individual. Individuals compare the newly acquired understanding or understanding with the criteria or norms that the individual has subjectively. Individual judgments are different even though the object is the same. Therefore, perception is individual.

According to Tandelilin (2010) indicators of investment decisions consist of:

a) Expected rate of return

b) Risk Level

c) Relationship between return and risk

In the context of investment management, the level of investment return is called return.

\section{Research Method}

The type of research conducted by the current researcher is qualitative research. With the population of the people in Manado City and sampled people with productive age between 15 - 64 years of age and income above five million rupiah. In this study, 50 samples were taken as respondents, this is based on a statement from Anggito \& Setiawan (2018) namely qualitative research, the number of samples does not need to be large but purposiveness, can be in the form of a snowball, content analysis, historiography and biographical evidence. Types of data and methods of data collection are done by interview. Interviews were conducted using the method Semi-Structured Interview through a video call, Part A begins by explaining the background of the research, research objectives, and the purpose of the interview which is included in the introductory text with a time of 10 minutes. Part $B$ is the interview process with a time of $10-15$ minutes. Part $\mathrm{C}$ is the closing part, give thanks 1 minute. In qualitative research, there are 5 phases in data analysis, namely: 1) collection, 2) disassembling, 3) reassembling, 4) interpretation and 5) conclusion (Yin, 2011: p. 177). With the first research steps, observing the public's perception of investment, this stage is carried out within a period of 1 month, that is April to May 2021. Second, conducting interviews with each resource person. Third, carry out data preparation, including editing data, categorizing and encoding based on a number of criteria. Fourth, analyzing the data with content analysis techniques according to (Yin, 2011) after the interview or data collection stages are carried out there are five stages in conducting data analysis, namely:

1) Arrange and sort notes or transcripts obtained from interviews and observations.

2) Giving new labels or codes and categorization on the parts that have been compiled.

3) Rearrange or recombine by describing the data graphically or by arranging 
it into a list or tabular form.

4) Reassembling the material to create a new narrative accompanied by relevant tables and graphs which will be a key part of the analysis of the manuscript concept.

5) Draw conclusions from all research analysis results.

Finally, the researcher prepares a final report and presents it to the university, to those who feel that they need the results of this research.

\section{Result and Discussion}

\subsection{Implementation}

The First Focus Is How the Public's Perception of Investment Products The sub focus consists of several things, namely:

1) Knowing whether the public knows about investment products and their reasons for investing

Indeed, the benefits and purpose of investing are to increase the number of assets and wealth owned. For someone who works, the return on investment is certainly an additional income. This research is also supported by research from Nurlaily (2020) where the results of interviews obtained are the factors that influence Lailatul Maghfiroh, an 8th semester Islamic Banking student to invest, namely: "Among the benefits that will be obtained, then by investing can add insight, also by investing can motivate yourself to set aside some.

2) Knowing whether the public knows about investment products in the capital market

Public knowledge of investment instruments in the capital market is still low, this is supported by previous research written by Kemu (2016) with conclusions First, the level of public literacy in the capital market is still very low. This results in low public participation in the capital market. Second, the causes of the low level of public literacy in the capital market are: a) Most people assume that to transact in the capital market requires large capital (hundreds of millions and even billions of rupiah), b) lack of technical knowledge about the capital market, c) public perception that transactions on the capital market exchange are gambling and contain usury which is unlawful, d) the occurrence of events that harm stock investors on the stock exchange due to fraud committed by brokers in the past creates a wrong perception in the community that playing stocks on the stock exchange vulnerable to fraud, e) the number and quality of human resources at OJK and SRO are not adequate in increasing the level of public literacy in the capital market. Third, the government has made several policies in order to increase public literacy on the capital market, such as: i) the trilogy of OJK policy instruments, namely financial inclusion, financial literacy (including capital markets) and consumer protection, ii) the three pillars of the National Strategy for Financial Literacy, namely: financial literacy, strengthening of financial literacy infrastructure and development of financial products and services, iii) participation of local governments and non-governmental institutions in con- 
ducting socialization of the financial sector and capital market to the public, whether carried out by the Indonesia Stock Exchange (IDX), KSEI, KPEI and other non-governmental public institutions such as banks and not-for-profit organizations.

1) The second focus is how the community's decisions in investing

The results of this study are supported by previous research, namely Dewi Ni Nyoman (2017) where the results show that risk factors affect interest invest. This is in line with the findings of this study that people who choose investment instruments know that most of them know with certainty the benefits and risks they will experience.

2) Knowing whether the public is aware of the risks of investing in the capital market

Based on the results obtained from interviews, it is known that there are still many people who do not understand the risks of investing in the capital market. This is caused by two things, people do not want to know, or there is still a lack of information that can be accepted by the community. As stated by Kaidah (2018) that the solution to increase student interest in investing in the capital market is frequent socialization, education by the OJK, the Stock Exchange or the gallery investment.

3) Knowing what investment instruments have been carried out by the community

Property and gold are the 2 investment instruments that respondents are most interested in. Around 46 people choose property and 36\% choose gold as their investment instrument. Looking at the analysis on gold investment and also investing in other financial instruments, it can be concluded that gold investment has more attractive advantages, both in terms of the prospective price level or the results obtained from these investments. In terms of investment risk, gold investment also has a lower risk percentage when compared to investments in other instruments. This can prevent losses that will be experienced by investors. From the two analyzes, the conclusion that can be drawn is that gold investment provides more profitable and safer results.

Slightly different from the results of the current study, the research written by Saputra, Herwono and Friends (2013) with the conclusion that the main portfolio choices of respondents are Cash Investments, Time Deposits and Money Market Mutual Funds.

4) Knowing whether the public owns stock/mutual funds/bonds

Only 4 respondents run stock investments, and 1 respondent runs mutual funds investment instruments. This research is supported by previous research written by Nurlaily (2020) with the results of 10 respondents who were students interviewed only 4 students who had invested in capital market and 6 people have not invested. Several informants who have invested in GI BEI in interviews stated that the things that made him decide to invest in GI BEI IAIN Ponorogo one of them is because of his knowledge of investment. Because students are still 
in the learning process. So it can be taken the essence of what is meant by respondents in previous research about the knowledge factor here, namely, the knowledge they already have about investment instruments in the capital market and the factor wanting to deepen their knowledge about investment instruments in the capital market.

5) Find out why they don't invest in the capital market

With various reasons stated by respondents, it is clear that the fear of risk caused by lack of information on the capital market makes people afraid to invest in the capital market.

The results of this study are in line with the results of research from Ni Made and Henny (2017) which states that information and socialization are sources of financial management knowledge. The importance of this is a big task for financial institutions to the community, especially people who already have a fixed income in the form of a monthly salary.

This result contradicts the results of research from Dewi Ni Nyoman (2017) that usually people who will invest avoid risk However, in the research of Nyoman Sri et al., it is found that the higher the risk accepted, the greater the interest in investing. This may be due to the fact that the students who were the sample in this study already had sufficient knowledge of the capital market, where to obtain high returns must be accompanied by high risk as well. Students are more interested in seeing the return (return) offered, so their perception of risk is also high.

\section{Closing}

\subsection{Conclusion}

From the results and discussion above, conclusions can be drawn based on the research objectives presented by the researchers, namely, to determine public perceptions of investment products and it can be concluded that the people of Manado City know clearly what their reasons are for investing. The profit in the future is their purpose of investing, of course, taking into account inflation and considering the cost of education which is getting more expensive by the day. The community already knows how to manage finances by setting aside a portion of their income to invest, as evidenced by all of the respondents who have implemented investment instruments with their respective varied choices.

Then the second goal is the community's decision to invest. In conclusion, the people of Manado City choose various investment instruments such as property, gold, deposits, businesses, plantations, Forex, foreign exchange, indexes, stocks, mutual funds, bonds. However, property and gold are the favorites of most people in Manado City

\subsection{Suggestion}

From the results of research and discussions that have been carried out by researchers as well as conclusions drawn, the researchers would like to provide 
suggestions:

1) Because of the result of research which shows that there is a lack of understanding of stock investment, because in general the respondents answered that they did not understand, it even required a large cost to invest in the capital market. Therefore, it is necessary to educate the capital market for all people in Manado City, in addition to continuing to provide education to students. It can be through a program directly from the Stock Exchange or from securities, or it can also be done through an investment gallery in the city of Manado.

2) Actually, there is a lot of information available in various media, but people don't understand when or how they have to study on their own, or read the term capital market. Therefore, a direct simulation needs to be given to the community, using examples such as directly showing how to open an account, how to transact using a cellphone so that it can be directly practiced by the community.

3) Financial management is also very important so that people can share their income for investment. Because the people of Manado city are famous for their consumptive culture. Therefore, it is necessary to provide good financial management knowledge, as well as good investment management so that people can distribute funds for investment, not only for consumption.

4) The PKM program is a program funded by an institution that aims for researchers to contribute directly in the form of service, it can be in the form of training, social service, development of research results and many other forms of service that can be given to the community. Therefore, it is necessary to carry out more PKM (Community Service) programs that reach the entire community to introduce stock investment instruments.

\section{Limitation of Research}

The Obstacle in this research is the pandemic condition so it is difficult to observe object. For the future we will focus on developing an investment gallery by providing education about investment instrument for the public and especially for the student. And Create Community Service or community partnership program to educate public about investment.

\section{Conflicts of Interest}

The authors declare no conflicts of interest regarding the publication of this paper.

\section{References}

Anggito, A., \& Setiawan, J. (2018). Metodologi Penelitian Kualitatif, Sukabum, CV Jejak.

Dewi Ni Nyoman, S. R. T. (2017). Modal Investasi Awal Dan Persepsi Risiko Dalam Keputusan Berinvestasi. Jurnal Ilmiah Akuntansi STIE Triatma Mulia, 2, 187.

https://investasi.kontan.co.id/news/jumlah-investor-di-pasar-modal-indonesia-masih-s edikit-ini-penyebabnya2020

Kaidah, N. (2018). Pengaruh Persepsi Mahasiswa Tentang Investasi Terhadap Minat In- 
vestasi Saham Di Pasar Modal Syariah. Skripsi, Lampung, UIN, p. 149.

Kemu, S. Z. (2016). Literasi Pasar Modal Masyarakat Indonesia (p. 173), Jurnal.

Ni Made, D. R., \& Henny, R. (2017). Pengaruh Tingkat Financial Literacy Dan Faktor Sosiodemografi Terhadap Perilaku Keputusan Investasi Individu (p. 3430). E-Jurnal Ekonomi dan Bisnis Universitas Udayana.

Nurlaily, A. E. (2020). Analisis Minat Investasi Mahasiswa FEBI IAIN Ponorogo UntukBerinvestasi DiGaleriInvestasi BEI IAIN Ponorogo Skripsi (p. 52, 63).

Saputra, Herwono, and Friends (2013). Jenis Investasi Berdasarkan Profil Risiko. Jurnal FE UKP, 2, 51.

Tandelilin, E. (2010). Portofolio dan Investasi Teori dan Aplikasi. Edisi pertama. Yogyakarta: Kanisius.

Walgito, B. (2010). Pengantar Psikologi Umum, Yogyakarta.

Yin, R. K. (2011). Qualitative Research from Start to Finish (p. 177). The Guilford Press. 